\title{
Amphiaraos, the Healer and Protector of Attika ${ }^{\dagger}$
}

LEE Sangduk*

\author{
1. Introduction \\ 2. The Amphiareion at Oropos \\ 3. Amphiaraos from Thebes: Change of Character from \\ Mantic to Healing \\ 4. Dispute over the Territory and another Amphiareion at \\ Rhamnous \\ 5. Promoting the Athenian Amphiaraos as the Healer and \\ Protector of Attika \\ 6. Conclusions
}

\section{Introduction}

Ancient Greek medicine has only enjoyed a marginal role in the history of medicine. Scientific aspect of medicine was more of interest, so its history was mainly aimed at tracing back the birth of scientific thoughts. Therefore, the focus of ancient Greek medicine was given mainly to investigating the surviving Hippocratic corpus and its philosophy. The healing gods of the Greek world and their magical treatments seemed

$\uparrow$ This work was supported by the Ministry of Education of the Republic of Korea and the National Research Foundation of Korea (NRF-2019S1A6A3A04058286).

* Research Professor, Ancient Greek History, the HK+ Institute for Integrated Medical Humanities, the Institute of Humanities, Kyung Hee University, Korea / email: s. catherine.lee@gmail.com 
less appealing to the researchers. Visiting the sanctuaries for healing was taken to be private and personal. Asklepios was the only healing god that managed to receive some attention due to his fame. Development in archaeology also appealed to the researchers to study the healing sanctuaries. The Athenian and the Epidaurian sites of Asklepian sanctuary were excavated in the last quarter of the nineteenth century. The cult of Asklepios was revisited through the newly founds and were introduced thereafter (Walton, 2010: 36-46). Yet again it was the irrational aspect of the cult that was highlighted. There were just a few books published, and a handful of researchers working on Asklepios in the following century. The Edelsteins published two monumental volumes on the epigraphic sources (Edelstein and Edelstein, 1945). Sara Aleshire worked on the subject and published the monograph, The Athenian Asklepieion: the People, their Dedications, and the Inventories (Amsterdam, 1989). She worked on the material finds. The work on archaeological evidence was carried on further by Jürgen Riethmüller. In his two volumes of Asklepios: Heiligtümer und Kulte. Studien zu antiken Heiligtümern (Heidelberg, 2005), he accumulated almost all available material evidence. This was a great establishment. A new approach, however, was made by a relatively small book by Bronwen Wickkiser in 2008. He argued that the cult of Asklepios was introduced to Athens with political intention. He further raised a possibility that the cult served for the empire. The idea had its roots in the discussion between rationality and irrationality of Greek medicine and is well presented in the Introduction of the book (Wickkiser, 2008: 2-7). I share the view with him that the cult did not merely serve as a healing place for private visits, while I go on further that the healing sanctuary in Athens especially served as a defence and 
protection of the polis territory, hence the importance of Amphiaraos whom I will discuss in this paper.

In Korea, too, history of ancient Greek medicine was concentrated to the scientific realm. Only from the end of the 2000s, some attempts to analyse the 'unscientific' figure, however restricted to Asklepios, began. There is no study yet published on Amphiaraos. KIM Hoyeon and YU Kangha, giving emphasis on the humanities therapy, carried on a comparative study between Chinese healing god Shen-nong and Asklepios (KIM and YU, 2008: 29-51). KIM Hoyeon expanded his part of the work to give an ample focus on the humanistic treatment by Asklepios (KIM, 2009: 44-76). His awareness and concern towards science-based treatments that consider patients as mere data is well shown in the works. CHO Eunjung, being a specialist in ancient iconography, analysed the images of Asklepios and other healing gods. She demonstrated that the 'saviour' god Asklepios grew to have a panhellenic significance (CHO, 2011: 5-42). This work from the discipline of classical archaeology could show the political aspect of Asklepios. SUNG Younggon showed an example of a figure named Aristides who zealously followed Asklepios' treatments (SUNG, 2016: 95-136). He compared the cultic treatment by Asklepios and Hippocratic medicine and argued that they were not mutually exclusive. The last and the most recent study related to Asklepios is the study of early hospitals by YEO Insok (YEO, 2017: 3-28). His main point was that hospitals were in the beginning charities that functioned as asylums for the needy. This certainly shows the changing perspective, for it was usually the modern building with good ventilation and practical design which was considered a hospital. There are only five studies listed above that deal with Asklepios in Korea, and they seem to 
share a similar notion: The development in modern medicine trapped itself inside the realm of science; humane and charitable treatment of the ancient times should once again be highlighted in order to raise criticisms about the modern medicine.

This is a very important view in the history of medicine, and moreover, today's development in the medical humanities and health studies. The wide spectrum of the understanding of medicine by the ancient Greeks should never be underestimated. They knew how to make use of irrational medicine for rational political manoeuvre. There was a rise in popularity of the healing hero/gods in the late fifth century BC and there were other healing hero/gods than Asklepios. In Athens, there was even an effort to promote another healing hero/god Amphiaraos in order to have one truly Athenian. It shows that there was more to it than healing in their function. Amphiaraos is a key figure in understanding the healing hero/gods in a wider sense. Unfortunately, Amphiaraos is not yet fully studied. In fact, there is no paper yet published in Korea that gives full attention to him. Only a relief had been introduced by CHO; and SUNG only mentions the name with a short description in the footnote (Cho, 2011: 29; Sung, 2016: 102, no. 23). Even among the western scholarship Amphiaraos did not receive due attention. He was only treated as a mere colleague of Asklepios (Wickkiser, 2008: 50-53; Petridou, 2016: 441-442). Sineux's work in 2007 is the only comprehensive work for Amphiaraos. He showed complex identity of Amphiaraos as a warrior, a divine, and a healer (Guerrier, Devin et Guérisseur). Otherwise, there are patches of work that are related. One important information of him comes from the studies on the Boiotian cults by Albert Schachter. Cults of Boiotia (London, 1981-), in four volumes, is not a book dedicated 
to Amphiaraos. But it offers valuable information about him in Boiotia. Archaeological reports especially in Oropos and Rhamnous also provide contextual information and makes it possible to understand the healing cult as a protection to the polis territory. Michael Cosmopoulos led a field-walk over the vast area of the Oropian plain; and Basileios Petracos studied the Amphiareion site. Jean Pouilloux made a careful examination on Rhamnous. This paper will try to gather all the scanty evidence and show that Amphiaraos was an important hero/god for the Athenians as a protector and healer. It will be stressed that the hero/god was not naturally developed but intentionally promoted by the Athenians in hopes to win the rivalry against her neighbours and to protect her homeland. Amphiaraos, as the healing god, not only functioned as a practitioner, but held symbolic meaning that had political effects. This study hopefully will enlarge the scope of not only the healing hero/gods but also modern medicine, moving away from the narrow understanding of medicine as science (that again, in a narrow sense).

\section{The Amphiareion at Oropos}

The Ancient polis of Athens was formed in two parts: the city centre called Athens surrounded by the walls, and the outer region that formed the wider Athens called Attika. Attika had sea on three sides but on the north, it was connected by land facing another Greek entity called Boiotia. Boiotia was a League of poleis of the region led by the Thebans. In the border area between Attika and Boiotia there were small towns that did not entirely belong to either sides. They were sometimes occupied by the Athenians, sometimes by the Boiotians, and during the fortunate 
years stayed independent. The Amphiareion was established by the Athenians in one of such towns: Oropos. Oropos was situated on the north-eastern border of Attika (about $50 \mathrm{~km}$ from Athens) and faced not only Boiotia but also Eretria across the strait on the island of Euboia (Pl. 1). The Athenians must have had strong intention of holding dominance over the city that they built a new sanctuary there as one of their efforts. It is remarkable that they chose to build a sanctuary for a healing hero/ god Amphiaraos. The Amphiareion was a healing sanctuary where many patients sought for healing. It is about $300 \times 200$ metres big and is divided into two parts by a ravine called Charadra in the middle. Facing East, on the left bank the official buildings for the sanctuary were positioned and on the other side, the residential area was formed. It should be noted that the sanctuary had similar features as that of the Asklepieion of Epidauros although smaller in scale (The Asklepieion is about $400 \times 600$ metres). Why was a healing sanctuary chosen to be positioned there? We first should look at the plan of the sanctuary.

Whereas today the sanctuary is accessible through a narrow passage between the temple and the stoa, in the ancient times, the entrance to the Amphiareion was located on the eastern end (Pl. 2). As one entered, the first building that he would encounter would have been the Women's baths. The foundation dates to the fourth century BC, but we do not have much of it left. The patients were required to purify themselves before the actual healing process. The next building is a long Stoa extending 110.15 metres long ( $\mathrm{Pl} .3)$. On the façade there were 39-41 Doric columns, and in the inside, there were 17 Ionic columns (Petracos, 1995: 25). The Stoa as in other Greek architecture must have served as a place where people rested and shared conversations. On the either end of the Stoa benches 
were found, and it may be here that the patients slept for the remedy (also called incubation). Behind the Stoa was the theatre (Pl. 4). Musical contests should have been held here during the Amphiaraia. In front of the Stoa seems to have been the stadium where the athletic events took place. The equestrian games should have taken place at the Hippodrome outside the sanctuary, in the plain situated to the north, nearby. There was annual festival for Amphiaraos, and there were Greater ones every four years from probably 329 BC (IG, VII 414; Parker, 2005: 457; Sineux, 2007: 102, n. 43). West to the Stoa, there was another older Stoa which had a series of statue pedestals displayed (Pl. 5). Decrees, honorary decrees, and dedications were displayed here. Next to the older Stoa there was a big altar. Two plaques that bear the name of Amphiaraos and Hestia are discovered at the altar and may be attributed to it (Paus. 1.34.3). ${ }^{1}$ The patients had to make animal sacrifices here in order to be healed (Sineux, 2007: 136-148). There are two other marble altars which are older but smaller and date to the fourth century BC (Petracos, 1995: 47). These should have been abandoned as the number of visitors increased. Southwest of the altar is the temple of Amphiaraos (Pl. 6). It is a simple temple of local limestone, with 6 Doric columns on the façade only (Petracos, 1995: 48-49). In the cella it is said that there was the marble statue of Amphiaraos and a table for libation (Paus. 1.34.2). To the south of the altar is the Sacred Spring which may be dated to the fifth century $\mathrm{BC}$, and it is here that Amphiaraos was believed to have risen from the earth. The cured patients threw coins into the water as to show veneration (Petracos, 1995: 51). Near the spring was the Men's Baths that

1) Pausanias also mentioned the names for the altar. It should be noted that the sleeping in the Amphiareion here does not necessarily mean incubation for healing. 
date to the fourth century BC. Across the ravine there was a residential area. This part was densely occupied during the festival seasons.

It should be noted that the key features of the sanctuary are similar with those of Asklepios at Epidauros. Just smaller in scale, but still in a considerable size, the Amphiareion had the key features of a healing sanctuary like the temple of the healing hero/god, the baths where the patients took bath before healing, the altar where the sacrifices took place, the temple to house the cult statue of the hero/god who receives the sacrifice, the Stoa, the simple room for incubation (in Epidauros it is the Abaton), the theatre and the stadium. The Amphiareion at Oropos was certainly a healing sanctuary benchmarking the Asklepieion (Charitonidos, 1978: 17).

When was the Amphiareion established? The archaeological finds are dated to the fourth century $\mathrm{BC}$, but we need to check with the literary sources in order to get closer to an accurate date. Herodotus never related the Amphiareion to Oropos but rather to Thebes (or the vicinity); when Mys went to an Ismenion at Thebes and bribed a certain stranger to sleep in the Amphiareion to test the oracle, Herodotus did not say where the Amphiareion was situated (Hdt. 8.134). The only hint for its location is the fact that he recorded the Amphiareion and the Trophonion together, as in vicinity (Hdt. 1.46). We know that the Trophonion was situated in Lebadea, within the Boiotian territory, and therefore the furthest we can get is to assume that this Amphiareion was somewhere in Boiotia; when the Amphiareion was revealed to be a credible oracle together with Delphi, Kroisos sent gifts to the Amphiareion, which in Herodotus' time were stored in the Ismenion at Thebes (Hdt. 1.52).

For the passage implies two different locations for the Amphiareion, 
there has been an effort to avoid that. ${ }^{2}$ Yet, we have several other reports to consider:

It is said that when Amphiaraos was fleeing from Thebes the earth yawned and swallowed him and his chariot: but they say that it did not happen here (Oropos), but at a place called Harma ('chariot') on the way from Thebes to Chalkis(Paus. 1.34.2).

On the way from Potniai to Thebes, on the right-hand side of the road, there is a small enclosure with pillars in it. They believe that here the earth yawned for Amphiaraos, and they add that birds do not perch on these pillars, and that no beast, wild or tame, browses on the grass that grows there (Paus. 9.8.3).

Near Oropos is a place called Graia, and also the temple of Amphiaraos $\cdots$ The temple of Amphiaraos was transferred hither in accordance with an oracle from the Theban Knopia (Strabo, 9.2.10).

In these sources Pausanias and Strabo refer to a place apart from Oropos for the location of the oracle (or sanctuary). Pausanias roughly explains the location that it is a place near Thebes. On the other hand,

2) Schachter discussed the long debate on whether the oracle that Kroisos consulted was in Oropos or not, starting from this piece of evidence (Schachter, 1981: 22, n. 2). He argued that there is no need to suppose a previous oracle site at Thebes if we believe the story that the Thebans had sacked and stolen the goods from the sanctuary at Oropos and moved them to Thebes (Schachter, 1981: 22). His basic tenet seems to be to avoid two different locations for the Amphiareion, and to stick to the one at Oropos. He rejected the aition given by Herodotus for the reason why the Thebans were banned from consulting the oracle at the Amphiareion. Herodotus explained this by recounting that Amphiaraos once bade the Thebans to choose either to take him as a prophet or an ally; the Thebans had chosen to become his ally (Hdt. 8.134). Schachter explained this as a rationalization by the Thebans of the hostility of the Oropians. He argued that the local hero of Oropos was named Amphiaraos for political reasons in order to show hostility against Thebes, where the hero was believed to have fallen (Schachter, 1981: 22). 
Strabo straightforwardly gives the name of the previous location as Knopia which is thought to be a town a short distance north from Thebes on the river Ismenus (cf. Schachter, 1981: 23). ${ }^{3)}$ He also explains that the temple was moved from Knopia to Oropos according to an oracle. Archaeological evidence for tracing the temple is scanty in both the Knopia area and Thebes; but, lack of evidence cannot speak for its nonexistence. The archaeological finds in the Amphiareion at Oropos speak for its establishment in the late fifth century BC for the sacred spring is dated to it. It is not unreasonable, therefore, to suppose that the oracle was transferred from a previous site near Thebes to Oropos.

Petropoulos plausibly derived the year of the foundation of the oracle in Oropos to between 420 and 414 (Petropoulos, 1981: 57-58). For the upper date he pointed out two factors: first, Asklepios was mentioned as a healing god in Aristophanes' Wasps which was put on stage in $422 \mathrm{BC}$, which is before the cult of Asklepios was introduced to Attika in 420 BC. If Oropos had the sanctuary of Amphiaraos at this time when Oropos was under the Athenian domination, there should have been no need for the Athenians to summon a hero all the way from Epidauros when they already have a healing hero within their territory. Second, there was hardly any construction going on during the Archidamian war (431-421 $\mathrm{BC}$ ). Archaeological surveys carried on the Oropian region also lead us to assume that the Amphiareion was built in the last quarter of the fifth century, and then grew to be popular in the fourth century (Travlos, 1988: 301). All the investigated fifth century BC settlements were still occupied

3) Schachter argued that Strabo's Knopia may have been the original toponym of Oropos. But his argument faces the difficulty of explaining Strabo's statement which says that the oracle of Knopia was Theban, and that the temple of Amphiaraos was transferred to Oropos (Graia), according to that oracle. 
in the fourth century BC, and the settlement area was expanded to eastern Oropos, to the areas of Vlastos and the Amphiareion. As for the lower date, we have a fragmentary play called Amphiaraos by Aristophanes which was produced in 414 BC (Henderson, 2007: 121; Storey, 2003: 83-84; Athenaios 216 D). ${ }^{4}$ This strongly indicates that Amphiaraos was fully introduced to the Athenians by then, and it may have possibly been produced with the new establishment in mind (Cosmopoulos, 2001: 58).

The evidence discussed above allows us to posit that the Amphiareion was formerly located near Thebes. Then sometime between 420 and 414 $\mathrm{BC}$ (probably in $414 \mathrm{BC}$ ) the sanctuary was moved to Oropos for some reason. As Pausanias had reported, Amphiaraos was believed to have fallen into a chasm near Thebes but he then 'was believed to have risen as a god at a spring near the Amphiareion' (Paus. 1.34.3).

\section{Amphiaraos from Thebes: Change of Character from Mantic to Healing}

In the course of moving the Amphiareion from Thebes to Oropos, one striking change was the change in the hero's character. Amphiaraos was at first a divine hero from Argos: he was known to be a descendent of Melampos (Od. 15.240-245) who had the power of divination through serpents and birds (Sineux, 2007: 30-31, esp. no. 40); and as we have seen above Kroisos and Mys went to his shrine for oracles. In the Seven Against Thebes, a tragedy by Aeschylus which was put on stage in 467

4) 'Testimonium: (Aristophanes) produced the play (Birds) at the City Dionysia through Kallistratos in the archonship of Charias ( $414 \mathrm{BC}$ ); he produced Amphiaraos at the Lenaia through Philonides.' 
$\mathrm{BC}$, he foresaw his death when proceeding to the war against Thebes (Aesch. Seven, 585-589, 617-618); also, he is called mantic several times. The Scout described him as the best seer (Aesch. Seven, 569: äpı $\mu \alpha \dot{v} \tau \imath \nu)$ and Eteokles named him 'the seer (ó $\mu \alpha \dot{v} \tau \imath \iota)$, Oikles' son, a moderate, just, noble, reverent man and a great prophet (Aesch. Seven,

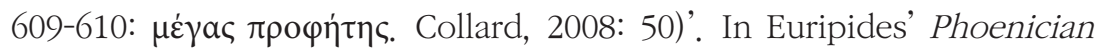
Women, Amphiaraos is again called the seer Amphiaraos (Eur. Phoen.

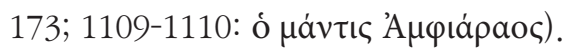

Amphiaraos is mostly depicted in departing scenes as a warrior hero, in the sixth- and fifth-century vase-paintings. The most typical type shows him either stepping up or already on the chariot, and in the background his wife Eriphyle, his son Alkmaion, and an old man are present. Significantly, two of these vase-paintings illustrate Amphiaraos' mantic character. The first is a fragment of a Corinthian column krater in Berlin by the Amphiaraos Painter. ${ }^{5)}$ It is dated to around 570 BC (Sineux, 2007: 246, fig. 1; Hurwit, 2006: 128). Amphiaraos, in full armour, stepping up into the chariot, turns around to see his family saying farewell to him: Alkmaion, Eurydika (inscribed), Damovanasa (inscribed), and Ainippa (inscribed) with Amphilochos on her shoulder are present, and Eriphyle holds in her hand Harmonia's necklace with which she was bribed to persuade his husband Amphiaraos to participate in the battle (Paus. 9.41.2). Baton (inscribed), Amphiaraos' chariot driver, is already on the chariot. Behind the horses stands Leontis (inscribed), and in front of the horses stands Hippotion (inscribed) and Halimedes (inscribed) sits on the ground with a staff. Animals are carefully deployed in the scene:

5) Berlin, Staatliche Museum, F 1665. 
above Halimedes are a snake and a bird; an owl is on one of the horses' head; a hare, a lizard and a hedgehog are depicted under Amphiaraos; another lizard is depicted on the left of the pillar of Amphiaraos' house and a scorpion on the pillar of the building of which Leontis is standing in front. The other painting is found on a fragment of a lekanis in Athens by the $\mathrm{C}$ Painter dated to the second quarter of the sixth century $\mathrm{BC}$ (Beazley, 1956: 58, no. 120; Sineux, 2007: 246). ${ }^{6}$ The scene is pretty much like the one described above but much simpler. Amphiaraos is again mounting the chariot (Baton is holding the rein) looking back. Only Alkmaion and Eriphyle appear to bid farewell to Amphiaraos. There is a trace of another person behind Eriphyle, but only a part of the figure is preserved and it is distant from the figure of Eriphyle, so one cannot be sure whether the figure is relevant to the scene at all. It is remarkable that a hedgehog is again depicted below Amphiaraos. Although only a part of it is remaining, it is clearly identifiable.

We can detect some of the features that attest to the mantic character of Amphiaraos. The old Halimedes who sits in front of Amphiaraos' chariot is himself a seer and knows the dreadful fate of Amphiaraos. He knows that the seven Argive generals including Amphiaraos will perish in battle against the Thebans. He brings his hand to his forehead; a convention to show one's grief (Hurwit, 2006: 128). The chthonic associations of the animals in the scene imply the destined death of the hero. Since Amphiaraos was believed to have been swallowed up by the earth, this connection is especially probable. Snakes were commonly regarded as chthonic, and scorpions and hedgehogs may be related to earth. Lizards,

6) Athens, National Museum, Acropolis Collection, 2112. 
according to Hurwit, had symbolised 'malevolent powers' and 'apotropaic device' (Hurwit, 2006: 130). Birds, on the other hand, although they could sometimes symbolise a spirit, they could also symbolise wisdom, especially owls like the one depicted above one of the horses' head. The elements of the iconography all lead to represent Amphiaraos' mantic character and his destined death.

From the late fifth century $\mathrm{BC}$, however, Amphiaraos is less depicted as a mantic hero but starts to be depicted as a healing hero/god, and there are many votive reliefs found in the Amphiareion site. The most famous is the votive relief now in Athens (Pl. 7, Petrakos, 1968: Pl. 40.a; Sineux, 2007: fig. 17; CHO, 2011: 16). ${ }^{7)}$ It was made of Pentelic marble (of Athenian origin) and is dated to the first half of the fourth century BC. It illustrates the incubation and has the following inscription written:

Archinos had it dedicated to Amphiaraos.

It has three separate scenes in one space. From the left, the first scene depicts Amphiaraos healing Archinos' arm. The second scene shows Archinos lying in a bed and a snake bites or licks his shoulder for healing on behalf of Amphiaraos. The last scene is showing Archinos offering a votive relief to Amphiaraos. Probably the most striking feature of the scene is that Amphiaraos is holding a scalpel and performs an actual medical treatment (Petridos, 2016: 441-442, cf. YEO, 2017: 10). He is not (represented as) using magical powers; but using medical technique. This indicates that the medical technique was already known at the time. If Amphiaraos was preferred to the actual medical treatment, then there

7) Athens, National Museum, 3369 (49 X $54.5 \mathrm{~cm})$. 
should have been a reason.

As the number of excavated votive reliefs dedicated to Amphiaraos increased from the fourth century BC, the number of vase-paintings depicting him as a seer or a warrior decreased. Amphiaraos from the fourth century BC was not merely a mythical hero but had become a real working god, giving practical help to the people. So, instead of being illustrated as a character in a myth, he was more depicted on votive gifts offered in return for the healing. Stoneman raised a plausible explanation for why such transformation happened:

The reason Amphiaraos developed as a healing deity may be twofold. First, the method of consultation, by incubation, was one already familiar to Athenians (and others) as that used predominantly for healing. Secondly, he was brought into Attica at almost exactly the same time as the healing god Asclepius, at the height of the Plague in Athens; so his function as a frontier defender may have been intensified by his role as a protector from sickness (Stoneman, 2011: 117).

It may be concluded that there was quite a clear transition in the character of the oracle and probably the transfer of the oracle site around the end of the fifth century BC, and now we turn to examine some practical reasons that may have to do with this transition.

\section{Dispute over the Territory and another Amphiareion at Rhamnous}

The Oropos Survey Project in 2001 led by Cosmopoulos has thoroughly surveyed the area dividing the region into small units. The 
surveys revealed that after a long period of abandonment the central and the western part of the Oropos region (which is called "the Oropia" comprising a wider region surrounding Oropos) was re-inhabited in the fifth century BC. All the units had traces of agriculture and pasture. Followed by the population growth in the later fifth century BC into the fourth, the occupied region was expanded to the east probably in search for more arable land. Cosmopoulos pointed out that the intensification was also a solution for satisfying the Athenian demands, and raised a possibility that these extended areas were occupied by Athenian cleruchs sent with the intention to control the area; which then must have led to transplanting the sanctuary of Amphiaraos (Cosmopoulos, 2001: 57, 62). According to him, it was "an act that allowed Athens to affirm her authority over the territory of Oropos and at the same time to create a nucleus of economic activity and exploitation of the countryside (Cosmopoulos, 2001, 75).'

Trade was also an important aspect of the Oropian economy. Its harbour was used for trade between Euboia and the cities on the mainland, namely Thebes and Athens (Moreno, 2007: 115-117). ${ }^{8)}$ The land route was considered preferable than the sea route to the Athenians for it was more secure (Westlake, 1948: 2-3). The Oropos-Dekeleian route was the fastest to reach Athens and therefore goods were transported by pack-animals (Westlake, 1948: 4). Pottery finds in the rural Oropia also speak for strong commercial relationship with Athens (Cosmopoulos, 2001: 76). The sanctuary also gained a substantial amount of income from the leased lands and donations and became the base to control the

8) He provides $I G \mathrm{I}^{3} 41,1.60,67-76$, dated to $446 / 5 \mathrm{BC}$ or after, as evidence for active 'seatraffic' between Attika and Euboia even before the Peloponnesian War. 
Oropia (Cosmopoulos, 2001: 80-81). It was therefore a critical matter for both Athens and Boiotia to found a sanctuary in such an important location.

Boiotia had always struggled against strong outside powers. It was necessary for the Boiotians to form a League (de facto the first Greek state to form a League) around the most powerful among them: Thebes (Hdt. 5.79; Buck, 1979: 107-120). The cities of Plataia, Erythrai, Hysiai, Eleutherai, Psaphis, and Oropos acted as buffers between Attika and Boiotia (Hdt. 6.101.1; Buck, 1979: 123). Especially Oropos had been tossed around among powers throughout its history. Oropos was ruled by Athens in the fifth century BC, but during the Peloponnesian War, in $412 / 11 \mathrm{BC}$, the Boiotians recaptured Oropos in cooperation with the Eretrians in support of the Lakedaimonian side (Thuc. 8.60.1; Buck, 1994: 19). In $387 / 6 \mathrm{BC}$, under the terms of the peace of Antalkidas, the Oropians gained freedom and became independent. This freedom did not last long, for soon in 378/7 BC, it came under Athens again and then in 367/6 $\mathrm{BC}$ under Eretria, and shortly after again under Thebes. Two inscriptions discovered near the Amphiareion at Oropos support the dating. The first stele is dated to between 402 and 387 BC by Petropoulos, for it shows that the Amphiareion accepted only the Boiotian drachma, implying that the shrine was under Boiotian (Theban) control (Sokolowski, 1962: 35; Petropoulos, 1981: 45 Pl. 1; 39-42; 58-59; Lupu, 2003: 333). The second stele, dated to between 387 and $377 \mathrm{BC}$, seems to be superseding the first one for it stipulated that the payment (eparche) for the healing was payable in any legal currency (Sokolowski, 1969: 69; Petropoulos, 1981: Pl. 2-4; 42-57; 59-61; Lupu, 2003: 333). Later in 338 BC, after the battle of Chaeronea, Philip handed over Oropos to Athens again. At 
this time a set of new regulations were published to control the taxes levied from the area ( $I G \mathrm{II}^{2}, 333$, 334; Humphreys, 2004: 85). Lykourgos focused on internal reform within Athens and rituals were highlighted again. The cult of Amphiaraos is believed to have been alluded to in the decree (Humphreys, 2004: 108-109; Petropoulos, 1981: 61). Oropos again enjoyed a short period of freedom between 322 and 313 BC, then Ptolemaios seized Oropos and subordinated it under the Boiotian Confederacy. Then in 304 BC Antigonos' son, Demetrios Poliorketes, gave the city back again to Athens. Oropos then in 287 BC probably gained short independence when the Athenians drove out Demetrios and his garrisons, and then belonged to the Boiotian Confederacy until 146 BC when it came under the Roman occupation (Petrakos, 1995: 8-9).

The tragic fate of Oropos was a result of endless rivalry among the surrounding powers. The Athenians were most eager to hold firm hand over the contested territory. Two forts have been mentioned by Ober in this area; one near the chapel of Aghia Paraskevi and the other on a $80 \mathrm{~m}$ hill looking over the Skala Oropou harhour (Ober, 1985: 138-139). Both were Athenian in respect of the masonry and seemed to have been built in the early fourth century BC. The two forts could see each other and had a view over the Oropian plain and the Euripos straits. Even the coastal cities of Euboia, Eretria and Chalcis, were visible on a clear day. 19-year-old ephebes patrolled the forts for defence. Ober's supposition that the two fortifications were "built as part of the same programme of construction that included the main circuit at Rhamnous' is plausible (Ober, 1985: 136-137, 140; Pouilloux, 1954: 43-66). Considering the importance of the Oropos-Rhamnous route it is most probable that these forts could communicate. Rhamnous was always an Attic deme, therefore building 
a strong connection between the two towns should have been important for keeping Oropos under control for the Athenians. The Athenian effort to control the region was made through both military action and religion. The building of forts and the change of character of Amphiaraos cannot be considered coincidental. Stoneman's understanding of Amphiaraos 'as a frontier defender' and 'as a protector from sickness' becomes more valid.

The Athenians indeed built another Amphiareion at Rhamnous which is about $17 \mathrm{~km}$ south from Oropos. The sanctuary is at the southwest of the main gate of the Rhamnousian fortress. The remains are so scanty that it is difficult to reconstruct the sanctuary. Again, we gain information from the archaeological evidence found around the site. A marble head dated to $480 \mathrm{BC}$ is identified with Aristomachos. ${ }^{9}$ ' Another head of a marble statue from the end of the fifth century $\mathrm{BC}$ is thought to be of Amphiaraos following the style of Asklepios in every aspect (Renberg, 2017: 272). ${ }^{10)}$ It is difficult to discern the change through the heads for they both represent a mature man, bearded. It is through the inscriptions that we can see that Amphiaraos slowly replaced Aristomachos in the span of the fourth to the third centuries BC. An inscription discovered at the entrance of the sanctuary is dated to the first half of the fourth century

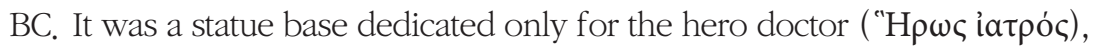
which was another name for Aristomachos (SEG, 50.168). Another statue base from the end of the fourth to the early third century names both Aristomachos and Amphiaraos. In the inscription about the repair of the sanctuary after the liberation in 229 BC, Aristomachos does not appear

9) London, British Museum, 2155.

10) Athens, National Museum, 2338. 
and it is implied that the sanctuary belongs solely to Amphiaraos ( $I G \mathrm{II}^{2}$, 1322).

The loss of Oropos in $322 \mathrm{BC}$ must have had an influence on the promotion of the Amphiareion in Rhamnous. The loss of the major healing sanctuary of the northeast region must have been backed up by the promotion of the Amphiareion in a nearby Rhamnous. The fact that the existing sanctuary in Rhamnous had been a healing shrine from the archaic times should indicate that the complete takeover by Amphiaraos was not only for healing purposes. If it was only for the function, the shrine could keep the old name. The name Aristomachos means "the one excellent in fighting" which recalls the fact that Amphiaraos himself was originally a general. Healing hero/gods became essential in the port areas for they were considered to protect the state from the perils that came from outside. The generals that fight against enemies and the healers that fight against epidemics seem to have been seen in parallel. Rhamnous was geopolitically important for it became the northern border when Oropos was not under the Athenian control. The defence of the deme was important and a series of reinforcements followed from the early fourth century BC; it was reinforced by the fortress in the first half of the fourth century, and the cult of Amphiaraos was transmitted from Oropos from the end of the fourth century BC. It becomes more impressive when we turn to how the Athenians made Amphiaraos solely Athenian.

\section{Promoting the Athenian Amphiaraos as the Healer and Protector of Attika}

Amphiaraos, originally, had Boiotian characteristics. Schachter 
introduced the term "Underground Oracle" in order to explain the shared features as follows:

The two members of this group are Amphiaraos and Trophonios: both were regarded as human beings who, on being pursued by an enemy were swallowed up by the earth and became oracular deities, possessed also of healing powers (Schachter, 1972: 22-23).

The Trophonion at Lebadeia was one of the six oracles situated around the shores of Lake Kopais in the Boiotian territory (Hdt. 8.134; Paus. 4.32-5.6; Schachter, 1967: 7). Since the oracles were clustered close by, they shared similar features. Schachter concentrated on this fact and expanded his interest to find a set of patterns in the Boiotian cults. He acknowledged that the Trophonian oracle followed a similar procedure to the one in the Amphiareion:

\begin{abstract}
(At the Amphiareion) The consultant, after spending several days in purification, slays a ram, and himself receives the oracular response, delivered while he sleeps on the hide of the ram. This too finds its reflection at the Trophonion, where the consultant himself descends to Trophonios in the night, after having spent several days in purification, and having slain a ram (Schachter, 1967: 9). ${ }^{11}$
\end{abstract}

He also recognised that both heroes descended into the earth after a pursuit by their enemies. Amphiaraos was hit by Zeus' thunderbolt while he was fleeing from Thebes pursued by Periklymenos. 'The earth opened

11) The full explanation by Pausanias is in Paus. 1.34.5. 
up and swallowed him (Pindar, Nemean Odes, 9.26).' Trophonios, fearing that he may be accused of stealing from the treasury, fled from Hyria and was pursued by Hyrieus. But again "the earth opened up and swallowed him (at Lebadea) (Paus. 9.37.5-7).' This experience did not only result in their ability to protect the territory, but also to heal. Being swallowed up by the earth, or to travel underground, was to become a protector and healer.

As for the Athenians, the striking similarity between the two heroes and the Boiotian identity of Amphiaraos in accordance had to be overcome in order to make Amphiaraos an Athenian. Athenians made a clever strategy to achieve this. They assimilated Amphiaraos not to Trophonios but rather to the Athenian mythical king, Erechtheus. Erechtheus is known to have fought in the war against the Eleusinians and the Thracians to protect the Athenian territory. The two heroes were assimilated through their (attitudes towards) death. Erechtheus' death is told thus: before he waged war against the Eleusinians, Erechtheus consulted an oracle which told that in order to win the battle he should sacrifice one of his daughters. He sacrificed one of his daughters and won the battle, killing Eumolpos. But he himself was avenged by Poseidon, who was the father of Eumolpos and was swallowed up by the earth (Eur., Ion, 277-284). The Erechtheion was built in the centre of the Acropolis commemorating his death. The death of Amphiaraos and Erechtheus are similar in the following ways; first, they both knew the dreadful destiny lying before them if they were going to attend the war. Amphiaraos knew that he was going to die and Erechtheus knew that he would have to kill (sacrifice) one of his daughters; second, they were both struck by the gods and swallowed up by the earth. Amphiaraos was hit by Zeus' thunderbolt 
and Erechtheus by Poseidon's trident; lastly, sanctuaries were built in commemoration of their deaths.

They were ready to sacrifice themselves for the sake of the fatherland and participated actively in their destiny. Their descent into the earth symbolised them living in and protecting the Athenian territory (chora) eternally. The fact that their sanctuaries were built after the deaths intensifies the argument. Erechtheus' sanctuary on the Acropolis was a house for many deities including Athena Polias, Poseidon, Hephaistos, and Erechtheus himself. It was here that the cult image of Athena representing the city of Athens was kept. If the Erechtheion protected Athens from the centre, the Amphiareion protected the border of Athens by protecting Athens from any disease or enemy coming in from outside. The gods' attitudes towards death show their determination to protect the land. they are well represented through two fragmentary tragedies by Euripides. In two fragmentary tragedies by Euripides, Amphiaraos and Erechtheus talk about death. Through their voices it becomes much clearer that the Athenians intended to create patriotic heroes protecting the fatherland.

The first play, Hypsipyle, starts when Amphiaraos, foreseeing his death in the war, asks Hypsipyle where he could find spring-water. Hypsipyle agrees despite the chorus' objections (Eur., Hypsipyle, F. 752h-k). She is at the time taking care of Eurydike's son, but, while she is not paying attention to him, he accidently dies. Eurydike is very angry with her (Hypsipyle) until Amphiaraos returns to the stage and persuades her to accept the misfortune. He renames the boy Archemoros ('First in Death') and suggests funeral games in commemoration of the child (Collard, Cropp, and Gilbert, 2004: 172-173). The child's death also resembles that 
of Amphiaraos and briefly follows the pattern I suggested above: sacrifi ce - death - commemoration. Amphiaraos shows his attitude towards death by the way he dealt with the death of the child. Collard, Cropp, and Gilbert in their commentary described Amphiaraos in this play as following:

Amphiaraos is idealized as a figure of wisdom and authority, piously fulfilling his religious duties as he goes towards his fate (F 752 h. 29-32, F 752 k. 20-1), conscious of the charis he owes to Hypsipyle (F 757.859, 871-3, F 759 a. 1584-6), reconciling Eurydice to her loss, and seeing the significance of her son's death (Collard, Cropp, and Gilbert, 2004: 181). ${ }^{12)}$

Death is something that one should accept, and therefore a good death should not be lamented but commemorated publicly.

In the second play by Euripides, Erechtheus, it is Praxithea (the wife of Erechtheus) rather than Erechtheus himself, who demonstrates the attitude towards death. In the beginning she refuses to sacrifice her daughter, but in the famous lines she changes her mind and voluntarily accepts her daughter's sacrifice (Eur., Erechtheus, F. 360). Collard, Cropp, and Lee explained the change of Praxithea:

The typical rhythm of Euripides' dramatizations of voluntary sacrificial death suggests that the sacrifice was resisted, then accepted after a decisive renunciation speech (Collard, Cropp,

12) Amphiaraos' understanding of death is well illustrated in the consolation for Eurydike (Eur. Hypsipyle, F 757.920-927): "No mortal was ever born who does not suffer. We bury children and get other new ones, and die ourselves; and mortals grieve at these things as they bring earth to earth. But so it must be: we must harvest life like a fruitful crop, and one of us live, one not. Why should we lament these things, which by our very nature must endure?' 
and Lee, 1995: 149).

The reasons that Praxithea gives is striking; first, it is because she has never found a city better than Athens, an autochthonous community; second, the reason for bearing children is to protect the god's altars and the fatherland; but most of all it is for virtue that she offers her daughter (Eur, Erechtheus, F. 28-29). Afterall 'a child is not a possession of the mother except through birth (Eur., Erechtheus, F. 38).' Like Amphiaraos, Praxithea does not suffer when her mind is set. Her love for the homeland reaches the culmination in the final lines of her speech:

My homeland, I wish that all your inhabitants loved you as I do: then we would dwell in you untroubled, and you would never be subjected to harm (F 360, 53-55; Collard, Cropp, and Lee, 1995: 161).

Although Amphiaraos was an Argive hero in the beginning, he was assimilated to Erechtheus and thus became the Athenian hero/god protecting the city.

\section{Conclusions}

The political situation in Athens from the end of the fifth century BC was not easy for the Athenians. In the final years of the Peloponnesian wars Athens was giving way to the Spartans and their allies. Thebes and Eretria were two powerful allies of the Spartans, and they were immediate danger for the Athenian north-eastern border. Oropos was situated there in the middle of three powers. Athenians put all their 
efforts in holding firm the piece of land. They set up forts and towers as fortifications but that was just not enough. They did what they were best at doing: myth-making. This time, it was not only the myth but an actual working sanctuary. The Athenians turned a Theban mantic hero into an Athenian healing god that treated the ill and wounded. The god not only welcomed the visitors for his festivals but invited them everyday for healing purposes. Many visited the site and understood Amphiaraos as Athenian.

The Athenian tragedy writer Euripides promoted Amphiaraos as Athenian by assimilating him with the mythical king of Athens, Erechtheus. Their similarity may be a result of pursuing patriotism in this period, but even so, it is meaningful that Amphiaraos was represented as a patriotic hero/god. He was the one that was swallowed up by the earth and then rose again, acquiring chthonic qualities that granted healing and protecting ability. It may be driven too far if we suppose Athenians trying to overcome a foreign healing god Asklepios by promoting their own, although it is obvious that they were benchmarking him. Asklepios was also a god famous to and loved by the Athenians. Amphiaraos should be considered as a local hero that had local significance but of no lesser importance. As the fortification programme and the establishment of the second Amphiareion at Rhamnous show, Amphiaraos was treasured by the Athenians as their healer and protector. He could not acquire the Greece-wide fame as Asklepios, for he was a local hero/god and the town that he was affiliated to (Oropos) changed hands many times. The fact that the Amphiareion at Oropos had to be substituted by the Amphiareion at Rhamnous shows the difficult territory that it was situated in. The healing god was until now only understood on the private level, as whom 
the patients sought after, but as we have seen through Amphiaraos, the healing hero/god could be taken as a political figure that was used at the state level. Healing was, by the ancient Athenians, understood in a wide spectrum and was considered as a way to protect the polis.

Keywords: Amphiaraos, Asklepios, Oropos, Attika, Healing god

Received: Jan. 31, 2020; Reviewed: Feb. 28, 2020; Accepted: Apr. 03, 2020 
LEE Sangduk : Amphiaraos, the Healer and Protector of Attika

\section{REFERENCES}

$\langle$ Bibliography >

Abbreviations

IG Inscriptiones Graecae

LIMC Lexicon Iconographicum Mythologiae Classicae

SEG Supplementum Epigraphicum Graecum

Secondary Sources

Ackermann, Hans C., Gisler and Jean-Robert, Lexicon Iconographicum Mythologiae Classicae (Zürich: Artemis, 1981).

Beazley, John D., Attic Black-figure Vase-painters (Oxford: Oxford University Press, 1956).

Buck, Robert J., A History of Boiotia (Alberta: The University of Alberta Press, 1979). -, Boiotia and the Boiotian League, 423-371 B. C. (Alberta: The University of Alberta Press, 1994).

Charitonidos, Angeliki, Epidaurus; the Sanctuary of Asclepios and the Museum (Athens: Clio editions, 1978).

CHO Eunjung, "The Asklepian Cult and the Iconography of Healing”, Korean Bulletin of Art History 37 (2011).

Collard, Christopher, Aeschylus: Persians and Other Plays (Oxford: Oxford University Press, 2008).

Collard, Christopher, Cropp, Martin J., and Gilbert, J., Euripides: Selected Fragmentary Plays Vol. 2 (Oxford: Aris \& Phillips, 2004).

Collard, Christopher, Cropp, Martin J., and Lee K. H., Euripides: Selected Fragmentary Plays Vol. 1 (Oxford: Aris \& Phillips, 1995).

Cosmopoulos, Michael B., The Rural History of Ancient Greek City States; the Oropos Survey Project, BAR International Series 1001 (Oxford: Archeopress, 2001).

Edelstein, Emma, J. and Edelstein, Ludwig, Asclepius: Collection and Interpretation of the Testimonies (Baltimore: JHU Press, 1945).

Faraone, Christopher A., "Aristophanes, Amphiaraus, Fr. 29 (Kassel-Austin): Oracular Response or Erotic Incantation?”, The Classical Quarterly, New Series, 42 no. 2 (1992), pp. 320-327. 
Heubeck, Alfred, "Amphiaraos”, Die Sprache; Zeitschrift fur Sprachwissenschaft 17 (1971), pp. 8-22.

Humphreys, S. C., The Strangeness of Gods: Historical Perspectives on the Interpretation of Athenian Religion (Oxford: Oxford University Press, 2004).

Hurwit, Jeffrey M., "Lizards, Lions and the Uncanny in Early Greek Art", The Journal of the American School of Classical Studies at Athens 75 no.1 (2006), pp. 121-136.

KIM Hoyeon, "A Discussion of 'Treatment' for the Humanistic Implications: Focusing on the Greek 'Healing God,' Asklepios”, History \& Culture 17 (2009).

KIM Hoyeon and Yu, Kangha, "A Comparative Research on Medicine and Myth in China and the West", The Journal of East-West comparative literature 18 (2008).

Lupu, Eran, "Sacrifice at the Amphiareion and a Fragmentary Sacred Law from Oropos", The Journal of the American School of Classical Studies at Athens 72 no. 3 (2003), pp. 321-340.

Parker, R., Polytheism and Society at Athens (Oxford, 2005).

Petrakos, Basileios. C., ho Oropos kai to hieron tou Amphiaraou (Athens: he en Athenais Archaiologike Hetaireia, 1968).

- The Amphiareion of Oropos (Athens: he en Athenais Archaiologike Hetaireia, 1995).

Petridou, Georgia, "Healing Shrine”, Irby, Georgia L. (ed.), A Companion to Science, Technology, and Medicine in Ancient Greece and Rome (New Jersey: Wiley, 2016).

Petropoulos, A., "The Eparche Documents and the Early Oracle at Oropus", Greek, Roman, and Byzantine Studies 22 (1981), pp. 39-63.

Pouilloux, Jean, La Forteresse de Rhamnonte (Paris: E. de Boccard, 1954).

Renberg, Gil, Where Dreams May Come: Incubation Sanctuaries in the Greco-Roman World (Leiden: Brill, 2017).

Schachter, Albert, "A Boiotian Cult Type”, Bulletin of the Institute of Classical Studies 14 (1967), pp. 1-16.

- "Some Underlying Cult Patterns in Boiotia", Teiresias Supplement 1 (Proceedings of the first International Conference on Boiotian Antiquities: McGill University, Montréal, 18.3. 1972), pp. 17-30. 
LEE Sangduk : Amphiaraos, the Healer and Protector of Attika

- Cults of Boiotia: 1. Acheloos to Hera, University of London Institute of Classical Studies Bulletin Supplement no. 38.1 (London: Institute of Classical Studies, 1981).

Sineux, Pierre, Amphiaraos; Guerrier, Devin et Guérisseur (Paris: les Belles Lettres, 2007).

Sokolowski, Franciszek, Lois Sacreé des cités grecques: Supplément (Paris: E. de Boccard, 1962).

— Lois Sacreé des cités grecques (Paris: E. de Boccard, 1969).

Stoneman, Richard, The Ancient Oracles; Making the Gods Speak (New Haven: Yale University Press, 2011).

SUNG Younggon, "Cures in Asklepieion and Hippocratic Medicine", The Journal of Classical Studies 46 (2016).

Travlos, J., Bildlexikon zur Topographie des Antiken Attika (Tübingen, 1988).

Walton, Alice, Asklepios; the Cult of the Greek God of Medicine (Montana: Kessinger publishing, 2010). This book is a facsimile reprint of the 1893 original.

Wickkeiser, Bronwen L., Asklepios, Medicine, and the Politics of Healing in Fifth Century Greece; Between Craft and Cult (Baltimore: The Johns Hopkins University Press, 2008).

YEO Insok, "The Birth of Hospital, Asclepius Cult and Early Christianity”, Korean Journal of Medical History 26 (2017). 
-Abstract-

\section{Amphiaraos, the Healer and Protector of Attika}

LEE Sangduk*

Amphiaraos was an important and popular healing hero/god in Athens from the end of the fifth century BC, however, not much has been studied. This paper investigates the figure in various ways by examining different sources. In the sixth century BC and in to the fifth, Amphiaraos was an Argive warrior hero that came into war against Thebes. He then seems to have acquired a sanctuary in the Theban territory being a mantic hero. In the end of the fifth century BC, however, he is said to have swallowed up by the earth and sprang up again in a spring at Oropos. Between 420-414 $\mathrm{BC}$, his sanctuary was set up by the Athenians at Oropos. But this time, he was venerated as a healing hero. In 420 BC, Asklepios was introduced to Athens in order to cure plague that went around from 430s BC. It seems that the Athenians benchmarked Asklepios to promote one more healing hero/god at their north eastern border. When Oropos was taken by their enemies, a substitute Amphiareion was established in Rhamnous,

\footnotetext{
* Research Professor, the HK+ Institute for Integrated Medical Humanities, the Institute of Humanities, Kyung Hee University, Korea / email: s. catherine. lee@gmail.com

Received: Jan. 31, 2020; Reviewed: Feb. 28, 2020; Accepted: Apr. 03, 2020
} 
a deme close to Oropos. The Athenians also promoted a patriotic hero through the words of Euripides. Illustrated as having gone through the same process of sacrifice - death - commemoration, Amphiaraos was put in parallel with the Athenian mythical king Erechtheus. Through this parallel, Amphiaraos became a political figure that protected Athens from outside threats. Healing was, by the ancient Athenians, understood in a wide spectrum and was considered as a way to protect the polis.

Keywords: Amphiaraos, Asklepios, Oropos, Attika, Healing god 


\section{$\langle$ Plates $>$}

1. The Map

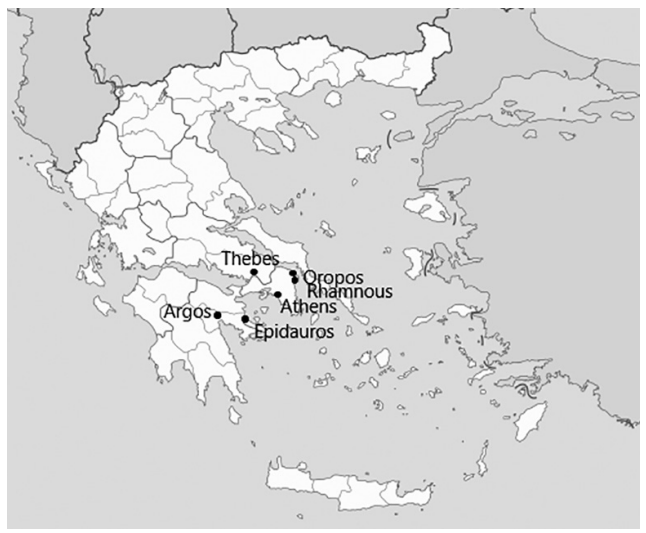

(By Lencer - own work, using United States National Imagery and Mapping Agency data, CC BY-SA 3.0, https://commons. wikimedia. org/w/index. php?curid=4432468, modified by the author)

2. The Amphiareion

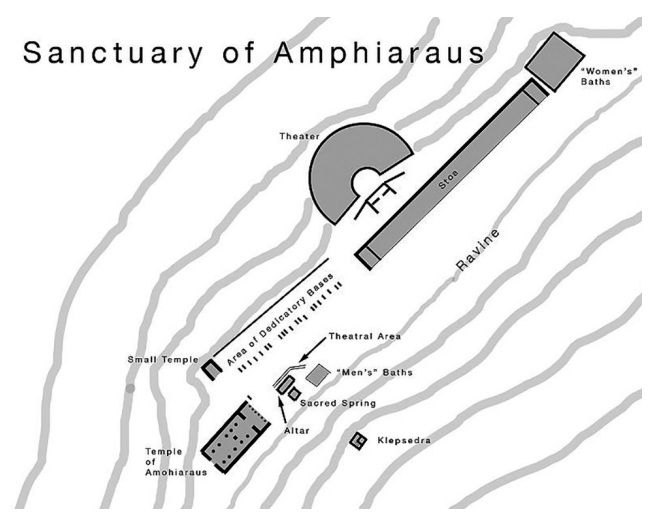

(By Nefasdicere at English Wikipedia, CC BY 2.5, https://commons.wikimedia. org/w/index.php?curid=5088397) 
LEE Sangduk : Amphiaraos, the Healer and Protector of Attika

3. The Stoa

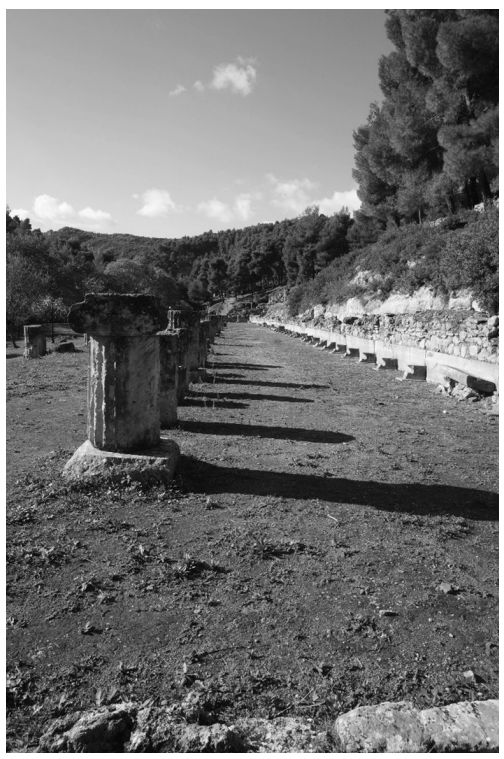

(photo by the author, 2013.11.17., from the Stoa, Oropos, Greece)

(photo by the author, 2013.11.17., in front of the Statue Pedastals, Oropos, Greece)

(photo by the author, 2013.11.17., from the Women's Baths, Oropos, Greece)

4. The Theatre

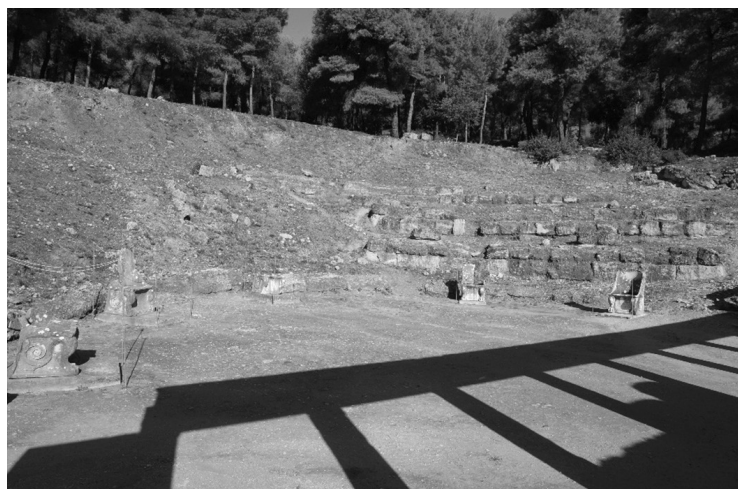

(photo by the author, 2013.11.17., facing north from the Stoa, Oropos, Greece) 
5. The Statue Pedestals

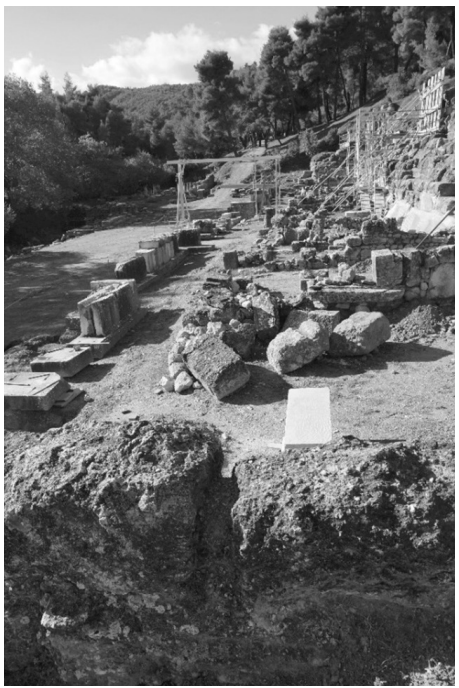

6. The Temple of Amphiaraos

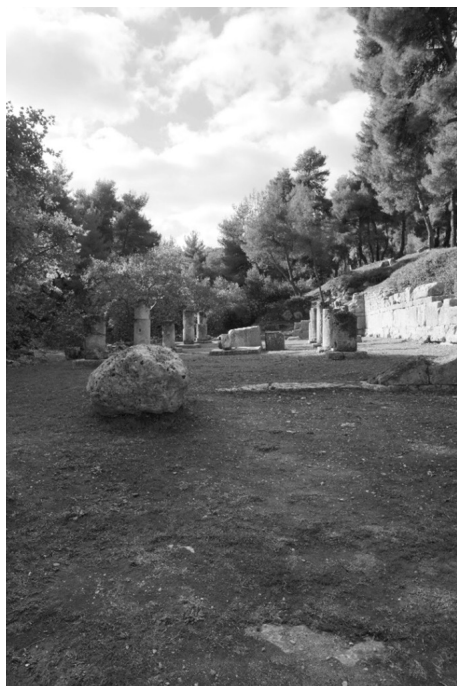

7. Athens, National Museum, 3369

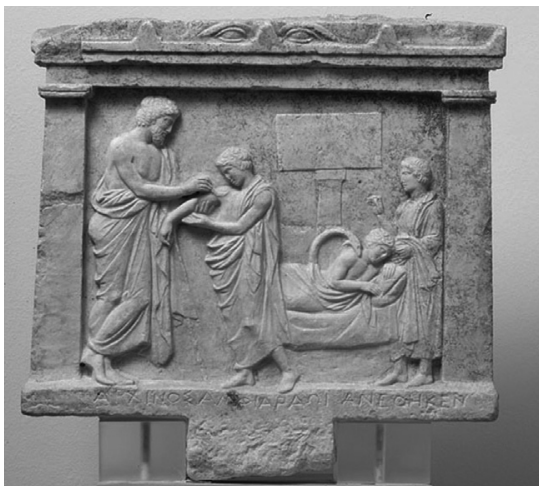

(Credit line National Archaeological Museum, Athens. Copyright (C) Hellenic Ministry of Culture and Sports /Archaeological Receipts Fund.) 
